\title{
EVALUASI FUNGSI AUDITOR INTERNAL DALAM PENDETEKSIAN DAN PENCEGAHAN FRAUD PADA PDAM AIRMADIDI
}

\author{
Brenda Yusensie Pua ${ }^{1}$, Jullie J. Sondakh ${ }^{2}$, Sonny Pangerapan ${ }^{3}$ \\ 1,2,3 Jurusan Akuntansi, Fakultas Ekonomi dan Bisnis, Universitas Sam Ratulangi, Jl. Kampus Unsrat, Kota \\ Manado, 95115, Indonesia \\ E-mail: brendapua918@yahoo.co.id
}

\begin{abstract}
Internal auditors have an important role in the company such as can provide suggestions for improvement within the company to avoid fraud that can lead to losses in the company. This study aims to determine whether the internal auditors in PDAM Airmadidi already run functions well and have been able to detect and prevent fraud in the company. The method used in this research is descriptive by describing the function of internal auditor through job description and internal auditor program in detecting and preventing fraud. The result of the research revealed that internal auditor function in detecting and preventing fraud in PDAM Airmadidi that internal auditor has performed function well can be seen from the duty of internal auditor: conduct examination either routine audit or special audit in which there is assessment on control system, supervision, inspection and provide suggestions for improvement within the company. The importance of management awareness of the internal control system within the company can also help to minimize the occurrence of fraud.
\end{abstract}

Keywords: Internal Auditor, Fraud, Internal Control System.

\section{PENDAHULUAN}

Didalam suatu perusahaan pasti terdapat bagian-bagian perusahaan,bagian-bagian ini dibedakan menjadi divisi. Semakin banyaknya divisi dalam perusahaan maka semakin besar presentasi terdapat kecurangan baik di dalam divisi itu sendiri atau dengan divisi yang lain bahkan antar perusahaan.

Fraud (Kecurangan) menggambarkan setiap upaya penipuan yang disengaja, yang dimaksudkan untuk mengambil aset atau hak pihak lain (Amin Widjaja:2016). Istilah fraud dalam konteks sederhana adalah perbuatan yang melanggar hukum. Perbuatan yang disebut fraud mengandung unsur kesengajaan, niat jahat, penipuan (deception), penyembunyian (concealment), dan penyalahgunaan kepercayaan (violation of trust). Perbuatan ini dilakukan untuk mengambil keuntungan haram (illegal advantage) yang berupa uang, barang/harta, jasa, penyuapan kepada petugas atau pejabat dalam kerahasiaan bisnis. (Theodorus $M$. Tuanakotta, 2014:28). Penelitian COSO menelaah hampir 350 kasus dugaan kecurangan pelaporan keuangan yang diselidiki oleh SEC. Hasil penelitian menunjukkan bahwa :

1. Kecurangan keuangan mempengaruhi perusahaan dari semua ukuran, dengan median perusahaan memiliki aktiva dan pendapatan hanya di bawah $\$ 100$ juta.

2. Median kecurangan adalah $\$ 12,1$ juta. Lebih dari 30 kasus dengan masing-masing kasus melibatkan jumlah lebih dari \$500 juta.

3. SEC menyebutkan CEO dan/atau CFO terindikasi terlibat pada $89 \%$ dari kasus kecurangan. Dalam waktu dua tahun penyelesaian penyelidikan SEC, sekitar 20\% dari para CEO/CFO berlanjut pada dakwaan serta lebih dari $60 \%$ di antaranya divonis bersalah.

4. Kecurangan mengenai pendapatan tercatat lebih $60 \%$ dari kasus.

5. Banyak karakteristik yang biasanya menjadi pengamatan umum dewan direktur dan komite audit, seperti: ukuran, frekuensi rapat, komposisi, serta pengalaman, tidak berbeda 
secara signifikan antara perusahaan yang terlibat kecurangan dengan yang tidak. Upayaupaya pengaturan tata kelola perusahaan terbaru tampaknya telah mengurangi variasi dalam karakteristik terkait dewan direktur yang diamati.

6. Dua puluh enam persen (26\%) dari perusahaan-perusahaan yang terlibat dalam kecurangan mengganti auditor selama periode yang diteliti dibandingkan dengan hanya $12 \%$ dari perusahaan-perusahaan yang tidak terlibat.

7. Berita awal dalam media massa mengenai dugaan adanya kecurangan mengakibatkan penurunan tidak normal harga saham rata-rata sebesar $16,7 \%$ untuk perusahaan yang terlibat kecurangan, dalam dua hari setelah pengumuman.

8. Berita mengenai investigasi SEC mengakibatkan penurunan tidak normal harga saham rata-rata $7,3 \%$.

9. Perusahaan yang terlibat dalam kecurangan sering mengalami kebangkrutan, delisting dari bursa efek, atau melakukan penjualan aset yang material dengan tingkat yang jauh lebih tinggi dari pada perusahaan yang tidak terlibat kecurangan. Jika dilihat dari pelaku fraud maka secara garis besar kecurangan bisa dikelompokkan menjadi dua jenis :

1. Oleh pihak perusahaan, yaitu :

a. Manajemen untuk kepentingan perusahaan, yaitu salah saji yang timbul karena kecurangan pelaporan keuangan (misstatements arising from fraudulent financial reporting).

b. Pegawai untuk keuntungan individu, yaitu salah saji yang berupapenyalahgunaan aktiva (misstatements arising from misappropriation of assets).

2. Oleh pihak di luar perusahaan, yaitu:

pelanggan, mitra usaha dan pihak asing yang dapat menimbulkan kerugian bagi perusahaan.

Dengan bertambah kompleksnya tugas-tugas manajemen, maka mereka tidak mampu melakukan pengawasan dan koordinasi yang efektif untuk seluruh perusahaan. Oleh karena itu manajemen perusahaan perlu dibantu oleh suatu unit yang khusus mengenai dan menelaah prosedur-prosedur dan operasi perusahaan.

Menurut laporan ACFE dalam "Report to Nation on Occuptional Fraud and Abuses" menyatakan bahwa aktivitas internal auditor dapat menekan $35 \%$ terjadinya fraud. Oleh karena itu pentingnya fungsi seorang internal auditor dengan tugas dan wewenangnya dapat mendeteksi dan mencegah kecurangan di tempat ia bekerja, karna auditor merupakan bagian dari pengendalian internal.

(dalam Ebrahim Mohhamed Al-Matari, Abdullah Kaid Al-Swidi \& Faudziah Hanin Binti Fadzil, 2014) menyatakan bahwa: 'Internal Audit makes a large contribution to the achievement of company goals, and the implementation of strategies for their achievement" Jadi auditor internal merupakan bagian yang memberikan kontribusi yang besar dalam pencapaian perusahaan. Auditor internal diharapkan akan dapat membantu anggota manajemen dalam berbagai hal, seperti menelaah prosedur operasi dari berbagai unit dan melaporkan hal-hal yang menyangkut tingkat kepatuhan terhadap kebijaksanaan pimpinan perusahaan, efisiensi, unit usaha atau efektifitas sistem pengawasan intern. Hal inilah yang melatar belakangi timbulnya spesialisasi bidang pemeriksaan intern, yang menuntut tidak hanya keahlian dalam bidang akuntansi tetapi juga keahlian bidang lainnya.

Untuk dapat mendeteksi dan mencegah kecurangan internal auditor harus memiliki keahlian sebagai eksistensi dari pengetahuan mengenai gejala pasti, pengertian akan masalah dan keahlian untuk menyelesaikan masalah tersebut. Oleh karena itu auditor internal berperan untuk mengidentifikasi program atau kegiatan yang memerlukan perbaikan atau penyempurnaan dalam rangka memberikan rekomendasi, agar pengelolaan program atau kegiatan organisasi dilaksanakan secara ekonomis, efisien, dan efektif sesuai dengan rencana dan ketentuan perundangan yang berlaku. 


\section{TINJAUAN PUSTAKA}

\subsubsection{Pengertian Akuntansi}

Akuntansi adalah suatu seni pencatatan, penggolongan, dan peringkasan, dengan cara yang informative dan diukur dalam bentuk mata uang, atas transaksi-transaksi atau kejadiankejadian keuangan perusahaan dan interpretasi hasilnya (Tanor, 2015). Menurut (Martani 2012:8) Akuntansi keuangan berorientasi pada pelaporan pihak eksternal. Beragamnya pihak eksternal dengan tujuan spesifik bagi masing-masing pihak membuat pihak penyusun laporan keuangan menggunakan prinsip dan asumsi-asumsi dalam penyusunan laporan keuangan. Untuk itu diperlukan standar akuntansi yang dijadikan pedoman baik oleh penyusun maupun oleh pembaca laporan keuangan. Laporan yang dihasilkan dari akuntansi keuangan berupa laporan keuangan untuk tujuan umum (general purpose financial statement).

\subsubsection{Definisi Internal Audit}

Menurut Sukrisno Agoes (2012:204) definisi dari audit internal adalah sebagai berikut : "Pemeriksaan intern (Internal audit) adalah pemeriksaan yang dilakukan oleh bagian internal audit perusahaan terhadap laporan keuangan dan catatan akuntansi perusahaan maupun ketaatan terhadap kebijakan manajemen puncak yang telah ditentukan dan ketaatan terhadap peraturan pemerintah dan ketentuan-ketentuan dari ikatan profesi yang berlaku. Peraturan pemerintah misalnya peraturan di bidang perpajakan, pasar modal, lingkungan hidup, perbankan, perindustrian, investasi, dan lain-lain”.

International Professional Practices Framework (2013), memberikan definisi Audit Internal sebagai berikut:

1. An independent, objective assurance and consulting activity designed to add value and improve an organisation's operations.

2. Helps an organisation accomplish its objectives by bringing a systematic, disciplined approach to evaluate and improve the effectiveness of risk management, control, and governance processes.

3. Aims to enhance the effectiveness, economy and efficiency of operations.

4. Covers all the operations and systems of the organization.

Definisi tersebut menerangkan bahwa audit internal tidak hanya sebatas pemeriksaan yang berkaitan dengan keuangan, namun lebih jauh dari itu mencakup reviu, evaluasi serta memberikan rekomendasi agar kegiatan perusahan menjadi efektif. . Menurut Arens, et.al (2012) auditing umumnya di golongkan menjadi 3 bagian sebagai berikut.

\section{Audit Laporan Keuangan (Financial Statement Audit)}

Audit laporan keuangan adalah audit yang dilakukan oleh auditor independen terhadap laporan keuangan yang disajikan oleh kliennya untuk menyatakan pendapat mengenai kewajaran laporan keuangan tersebut. Dalam audit laporan keuangan ini, auditor independen menilai kewajaran laporan keuangan atas dasar kesesuaian dengan prinsip akuntansi yang berlaku umum. Hasil auditing atas laporan keuangan tersebut disajikan dalam bentuk tertulis berupa laporan audit.

2. Audit Kepatuhan (Compliance Audit)

Audit kepatuhan adalah audit yang tujuannya untuk menentukan apakah yang diaudit sesuai dengan kondisi atau peraturan tertentu. Hasil audit kepatuhan umumnya dilaporkan kepada pihak yang berwenang membuat kriteria. Audit kepatuahn banyak ditemui dalam pemerintahan.

3. Audit Operasional (Operational Audit)

Audit operasional merupakan reviu secara sistematik kegiatan organisasi, atau bagian dari padanya, dalam hubungannya dengan tujuan tertentu. Tujuan audit operasional adalah untuk: (1) Mengevaluasi kinerja, (2) Mengidentifikasi kesempatak untuk peningkatan, (3) Membuat 
rekomendasi untuk perbaikan atau tindakan lebih lanjut. Pihak yang memerlukan audit operasional adalah manajemen atau pihak ketiga.

\subsubsection{Laporan Audit Internal}

Sebagai hasil dari pekerjaannya, internal auditor harus membuat laporan kepada manajemen. Laporan audit yang disusun akan memiliki kualitas yang baik jika selama perencanaan dan pekerjaan lapangan juga mengahasilkan kualiatas yang baik, dalam penyusunan laporan audit internal pada umumnya terdiri dari:

1. Draf laporan audit

2. Laporan audit individual final

3. Laporan triwulanan

4. Laporan tahunan

Laporan tersebut merupakan suatu alat dan kesempatan bagi internal auditor untuk menarik perhatian manajemen dan membuka mata manajemen mengenai manfaat dari Internal Audit Department (IAD), apa saja yang sudah dan dapat dikerjakan IAD, hal penting apa saja yang terjadi di perusahaan dan memerlukan perhatian dan tindakan perbaikan dari manajemen, laporan audit juga merupakan sebuah informasi. Menurut Marshall B. Romey, Paul John Steinbart (2014:3) dalam buku Accounting Information System diterjemahkan oleh Kikin Sakinah dan Novita Puspasari, informasi adalah data yang telah dikelola dan diproses untuk memberikan arti dan memperbaiki proses pengambilan keputusan.

\subsubsection{Fungsi Internal Auditor}

Pada mulanya internal auditor dalam suatu perusahaan mempunyai fungsi yang terbatas, yaitu mengadakan pengawasan atas pembukuan, namun sejalan dengan meningkatnya sistem informasi akuntansi, aktivitas internal auditor tidak lagi berputar pada pengawasan pembukuan semata-mata.Akan tetapi mencakup pemeriksaan dan evaluasi terhadap kecukupan dan efektivitas sistem organisasi, sistem internal control dan kualitas kertas kerja manajemen dalam melaksanakan tanggung jawab yang dibebankan kepadanya. Menurut Faiz Zamzami,dkk (2016:23) Sesuai dengan international standards for the professional practice of internal auditing 2013, 2120.A2 menyebutkan aktivitas audit internal harus mengevaluasi potensi terjadinya kecurangan dan bagaimana organisasi mengelola risiko kecurangan.

Internal auditor tidak hanya berfungsi untuk mengurangi kebocoran dalam perusahaan, akan tetapi lebih dari itu yaitu sebagai penghasil informasi yang tepat dan tidak memihak serta dapat mernbantu meningkatkan mutu pimpinan dalam pengendalian perusahaan. Internal auditor harus memiliki kecakapan yang luas menilai dan mengevaluasi berbagai hasil yang telah dicapai manajemen, mampu mendeteksi dan mengantisipasi kelemahan yang mungkin terjadi di masa depan dan menciptakan saluran komunikasi pada berbagai tingkat kegiatan dalam manajemen. Dalam sektor publik, Government Accountability Office (GAO) dan Ikatan Akuntan Indonesia (IAI), memiliki pendapat yang sama tentang kualitas audit yaitu ketaatan terhadap standar profesi dalam arti audit dikatakan berkualitas jika memenuhi standar auditing dan standar pengendalian mutu (Turangan,Feibe Maria,dkk 2016:72). Fungsi auditor internal yang dikutip yang ditulis oleh (Faiz Zamzani, dkk 2016:34) sebagai berikut.

1. Mengevaluasi risk exposure yang berkaitan dengan pencapaian tujuan organisasi yang strategis.

2. Mengevaluasi keandalan dan intergritas informasi dan cara yang digunakan untuk mengidentifikasi, mengukur, mengklasifikasi, dan melaporkan informasi tersebut.

3. Mengevaluasi penyediaan sistem untuk memastikan kepatuhan dengan kebijakankebijakan, rencana, prosedur, hukum, dan peraturan yang dapat memiliki dampak yang signifikan pada organisasi. 
4. Mengevaluasi sarana aset pengamanan dan jika perlu memverifikasi keberadaan aset tersebut.

5. Mengevaluasi efektivitas dan efisiensi sumber daya yang digunakan.

6. Mengevaluasi operasi atau program untuk mamastikan apakah hasilnya konsisten dengan tujuan yang dibuat serta sasaran dan apakah operasi atau program yang sedang dilakukan telah sesuai sebagaimana yang direncanakan.

7. Memantau dan mengevaluasi proses tata kelola.

8. Memantau dan mengevaluasi efektivitas manajemen risiko organisasi proses.

9. Mengevaluasi kualitas kinerja auditor eksternal dan tingkat koordinasi dengan audit internal.

10. Melakukan konsultasi dan jasa konsultasi terkait dengan tata kelola, menajemen risiko, dan control yang sesuai untuk organisasi.

11. Membuat laporan berkala pada aktivitas audit internal tentang tujuan, wewenang, tanggung jawab, dan kinerja relatif terhadap rencananya.

12. Membuat laporan signifikan risk exposure dan masalah pengendalian, termasuk risiko kecurangan, isu-isu pemerintah, dan hal-hal lain yang diperlukan atau diminta oleh dewan.

13. Mengevaluasi operasi tertentu atas permintaan dewan atau manajemen.

\subsubsection{Posisi Internal Auditor Dalam Struktur Organisasi}

Audit internal harus ditempatkan pada posisi yang memungkinkan fungsi tersebut memenuhi tanggungjawabnya (Amin Widjaja, 2015:33).Secara garis besar ada tiga alternatif posisi atau kedudukan dari Internal Auditor dalam struktur organisasi perusahaan yaitu:

1. Berada dibawah Dewan Komisaris.

Dalam hal ini staf internal auditing bertanggung jawab pada Dewan Komisaris. Ini disebabkan karena bentuk perusahaan membutuhkan pertanggungjawaban yang lebih besar, termasuk direktur utama dapat diteliti oleh internal auditor. Dalam cara ini, bagian pemeriksa intern sebenarnya merupakan alat pengendali terhadap performance manajemen yang dimonitor oleh komisiaris perusahaan. Dengan demikian bagian pemeriksa intern mempunyai kedudukan yang kuat dalam organisasi.

2. Berada dibawah Direktur Utama.

Menurut sistem ini staf internal auditor bertanggungjawab pada direktur utama. Sistem ini biasanya jarang dipakai mengingat direktur utama terlalu sibuk dengan tugas-tugas yang berat. Jadi kemungkinan tidak sempat untuk mempelajari laporan yang dibuat internal auditor.

3. Berada dibawah Kepala Bagian Keuangan.

Menurut sistem ini kedudukan internal auditor dalam struktur organisasi perusahaan berada dibawah koordinasi kepala bagian keuangan. Bagian internal auditor bertanggung jawab sepenuhnya kepada kepala keuangan atau ada yang menyebutnya sebagai Controller. Tapi perlu juga diketahui bahwa biasanya kepala bagian keuangan tersebut bertanggung jawab juga pada persoalan keuangan dan akuntansi. 


\subsubsection{Perbedaan antara Auditor Internal dan Auditor Eksternal}

Tabel 2.1

Perbedaan Auditor Internal dengan Auditor Eksternal

\begin{tabular}{|c|c|c|c|}
\hline NO & KETERANGAN & $\begin{array}{l}\text { AUDITOR } \\
\text { INTERNAL }\end{array}$ & $\begin{array}{c}\text { AUDITOR } \\
\text { EKSTERNAL }\end{array}$ \\
\hline 1. & Pemberi Kerja & $\begin{array}{l}\text { Perusahaan dan Unit- } \\
\text { Unit Pemerintah }\end{array}$ & $\begin{array}{c}\text { Kantor Akuntan } \\
\text { Publik }\end{array}$ \\
\hline 2. & Organisasi Nasional & $\begin{array}{l}\text { Institute of Internal } \\
\text { Auditor (IIA) }\end{array}$ & $\begin{array}{l}\text { American Institute of } \\
\text { Certified Public }\end{array}$ \\
\hline 3. & Gelar Sertifikasi & $\begin{array}{l}\text { Certified Internal } \\
\text { Auditor (CIA) }\end{array}$ & $\begin{array}{c}\text { Certified Public } \\
\text { Accountant (CPA) }\end{array}$ \\
\hline 4. & $\begin{array}{c}\text { Tanggung jawab } \\
\text { Utama }\end{array}$ & $\begin{array}{l}\text { Kepada Dewan } \\
\text { Komisaris }\end{array}$ & Kepada Pihak Ketiga \\
\hline 5. & $\begin{array}{c}\text { Ruang Lingkung } \\
\text { Audit }\end{array}$ & $\begin{array}{c}\text { Semua Aktivitas } \\
\text { Dalam Suatu } \\
\text { Organisasi }\end{array}$ & $\begin{array}{l}\text { Terutama Laporan } \\
\text { Keuangan }\end{array}$ \\
\hline
\end{tabular}

Sumber: Amin Widjaja (2015:29)

\subsubsection{Peran Internal Auditor Dalam Mendeteksi dan Mencegah Fraud}

Kecurangan biasanya tidak hanya dilakukan oleh karyawan pada tingkat bawah, tetapi juga dapat dilakukan oleh jajaran direksi (top management) baik secara individual maupun bersama-sama (fraud management) yang dalam cakupan penugasan audit mungkin luar jangkauan kewenangan internal auditor.

Standar Profesi Audit Internal (1210.2) yang disusun oleh Institute of internal auditor (2012) menyatakan bahwa internal audit harus memiliki pengetahuan yang memadai untuk dapat mengenali, meneliti, dan menguji adanya indikasi kecurangan. Audit internal juga diminta untuk menginformasikan kepada pejabat yang berwenang dalam hal diduga telah terjadi penyimpangan, dan menindaklanjutinya untuk meyakinkan bahwa tindakan yang tepat telah dilakukan untuk memperbaiki masalah yang ada.Terdapat 4 pilar utama dalam memerangi kecurangan, yaitu :

1. Pencegahan kecurangan (fraud prevention).

2. Pendeteksian dini kecurangan (early fraud detection).

3. Investigasi kecurangan (fraud investigation).

4. Penegakan hukum atau penjatuhan sanksi (follow-up legal action).

\subsection{Konsep Kecurangan (Fraud)}

\subsubsection{Definisi Kecurangan}

Fraud merupakan istilah hukum yang diserap ke dalam disiplin akuntansi, dan menjadi bagian yang penting dalam kosa kata akuntansi forensik. Salah satu definisi fraud (Tuanakotta, 2013:28) mengatakan bahwa " Any illegal acts characterized by deceit, concealment, or violation of trust. These acts are not dependent upon the application of threats of violence or physical force. Frauds are perpetrated by individuals, and organizations to obtain money, property or services; to avoid payment or loss of services; or to secure personal or business advantage". Definisi di atas dapat diartikan sebagai berikut:

1. Fraud adalah perbuatan melawan hukum.

2. Perbuatan yang disebut fraud mengandung: unsur kesengajaan, niat jahat, penipuan (deception), penyembunyian (concealment), penyalahgunaan kepercayaan (violation of trust). 
Fraud adalah sebuah istilah di bidang IT yang artinya sebuah perbuatan kecuranganyang melanggar hukum (illegal-acts) yang dilakukan secara sengaja dan sifatnya dapat merugikan pihak lain. Istilah keseharian adalah kecurangan diberi nama yang berlainan seperti pencurian, penyerobotan, pemerasaan, penjiplakan, penggelapan, dan lain-lain. Orang awam sering kali mengartikan bahwa fraud secara sempit adalah tindak pidana atau perbuatan korupsi. Fraud atau kecurangan itu sendiri adalah tindakan yang melawan hukum oleh orangorang dari dalam dan atau luar organisasi, dengan maksud untuk mendapatkan keuntungan pribadi dan atau kelompoknya yang secara langsung merugikan pihak lain. Dari beberapa definisi atau pengertian fraud diatas, maka yang dimaksud dengan fraud adalah sangat luas dan dapat dilihat pada beberapa kategori kecurangan. Namun secara umum, unsur-unsur dari kecurangan adalah :

1. Harus terdapat salah pernyataan (misrepresentation).

2. Dari suatu masalah masa lampau (past) dan sekarang (present).

3. Fakta bersifat material.

4. Dilakukan secara sengaja atau tanpa perhitungan (make - knowingly or recklessly).

\subsubsection{Kategori Kecurangan}

The Association of Certified Fraud Examiners (ACFE) atau Asosiasi Pemeriksa Kecurangan Bersertifikat, merupakan organisasi profesional bergerak dibidang pemeriksaan atas kecurangan di AS memiliki tujuan untuk memberantas kecurangan, mengklasifikasikan kecurangan (fraud) dalam beberapa klasifikasi dan dikenal dengan istilah "Fraud Tree" yaitu sistem klasifikasi mengenai hal-hal yang ditimbulkan oleh kecurangan yang sama(Uniform Occuptional Fraud Classification System) membagi Fraud menjadi 3 jenis sebagai berikut:

1. Penyimpangan Atas Aset (Asset Missappropriation).

Penyalahgunaan, pencurian asset atau harta perusahaan atau pihak lain, jenis ini paling mudah untuk dideteksi karena sifatnya tangiable atau dapat diukur/dihitung (defined value).

2. Pernyataan Palsu (Fraudulent Statement).

Tindakan yang dilakukan oleh pejabat atau eksekutif suatu perusahaan atau instansi pemerintah untuk menutupi kondisi keuangan yang sebenarnya dengan melakukan rekayasa keuangan (financial engineering) dalam penyajian laporan keuangannya untuk memperoleh keuntungan atau mungkin dapat dianalogikan dengan istilah window dressing.

3. Korupsi (Corruption).

Jenis fraud ini yang paling sulit dideteksi karena menyangkut kerjasama dengan pihak lain seperti suap dan korupsi, dimana hal ini yang merupakan jenis yang terbanyak di negaranegara berkembang yang penegakan hukumnya lemah dan masih kurang kesadaran akan tata kelola yang baik sehingga faktor integritasnya masih dipertanyakan, fraud jenis ini sering kali tidak dapat dideteksi karena para pihak yang bekerja sama menikmati keuntungan (simbiosis mutualisme) termasuk di dalamnya adalah penyalahgunaan wewenang/konflik kepentingan (conflict of interest), penyuapan(bribery) dan penerimaan yang tidak sah/ilegal (illegal gratuities)

\subsubsection{Faktor-Faktor Penyebab Kecurangan}

Terdapat empat faktor pendorong seseorang untuk melakukan kecurangan, yang disebut juga dengan teori GONE yang dikemukakan oleh Jack Bologne (dalam Rahadian : 2014) yaitu : (1) Greed (keserakahan), (2) Opportunity (kesempatan), (3) Need (kebutuhan), (4) Exposure (pengungkapan).

Menurut SAS 99 (AU 316) yang dikutip oleh Amin Widjaja Tunggal (2016:9) terdapat tiga faktor seseorang melakukan kecurangan yang dikenal sebagai "fraud triangle" 


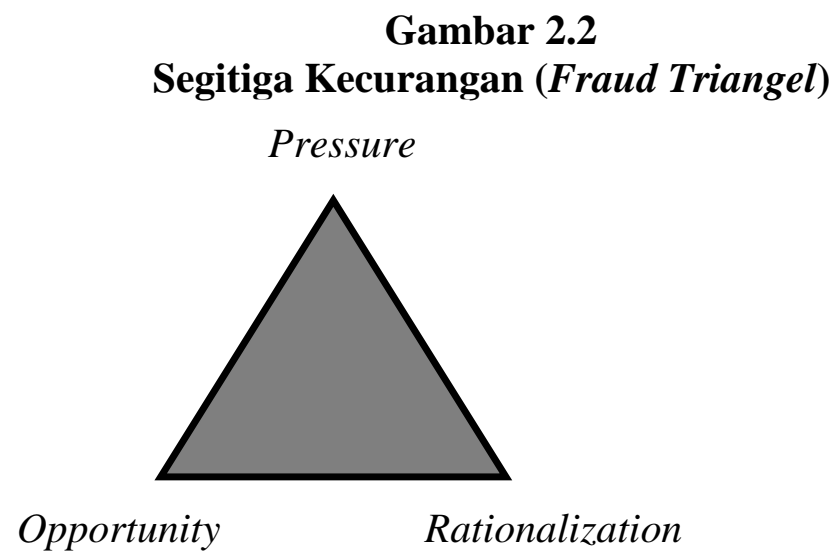

Sumber: Amin Widjaja Tunggal (2016:9)

a. Tekanan (Pressure): dorongan seseorang untuk melakukan kecurangan yang dipicu oleh alasan ekonomi, emosional, atau nilai.

b. Peluang (Opportunity) : kondisi yang memberikan peluang pada seseorang untuk melakukan kecurangan. Misalnya lemahnya internal kontrol atau penyalahgunaaan wewenang.

c. Rasionalisasi (Razionalization): pelaku mencari pembenaran sebelum melakukan kecurangan. Seseorang melakukan rasionalisasi agar dirinya dapat mencerna tindakannya yang ilegal agar tetap dapat mempertahankan jati dirinya sebagai orang yang dipercaya.

\subsection{Pengendalian Internal}

\subsubsection{Definisi Pengendalian Internal}

Menurut COSO (Committee of Sponsoring Organizations of the Treadway Commission) (2013), "Pengendalian internal adalah suatu proses yang dilakukan oleh dewan entitas direksi, manajemen, dan personil lainnya dirancang untuk memberikan keyakinan memadai tentang pencapaian tujuan yang berkaitan dengan operasi, pelaporan, dan kepatuhan." Pengendalian internal mencakup rencana organisasi dan semua metode yang terkoordinasi yang diterapkan, antara lain untuk mengamankan harta perusahaan, keakuratan dan keandalan sistem akuntansi dan keuangan, meningkatkan efisiensi operasional, dan mendorong ketaatan terhadap kebijakan manajerial yang telah ditetapkan. Sehingga pengendalian internal tidak sebatas pada fungsi akuntansi dan keuangan, melainkan mencakup keseluruhan fungsi pada perusahaan. Sistem Pengendalian Internal terdiri atas lingkungan pengendalian, penilaian resiko, prosedur pengendalian, informasi dan komunikasi, serta pemantauan pengendalian. Sistem pengendalian internal yang handal dan efektif dapat memberikan informasi yang tepat bagi manajer maupun dewan direksi yang bagus untuk mengambil keputusan maupun kebijakan yang tepat untuk pencapaian tujuan perusahaan yang lebih efektif pula. Sistem Pengendalian Internal berfungsi sebagai pengatur sumber daya yang telah ada untuk dapat difungsikan secara maksimal guna memperoleh pengembalian yang maksimal pula dengan pendekatan perancangan yang menggunakan asas Cost-Benefit.

Tujuan penerapan SPI dalam perusahaan adalah untuk menghindari adanya penyimpangan dari prosedur, laporan keuangan yang dihasilkan perusahaan dapat dipercaya dan kegiatan perusahaan sejalan dengan hukum dan peraturan yang berlaku. Hal ini menunjukkan bahwa perusahaan terutama manajemen berusaha untuk menghindari resiko dari adanya penerapan suatu sistem. Adapun tujuan Sistem Pengendalian Internal secara umum dalam suatu organisasi/perusahaan adalah

1. Menjaga kekayaaan dan catatan organisasi. 
2. Mengecek ketelitian dan keandalan data akuntansi.

3. Mendorong efisiensi dengan menggunakan sumber daya dan sarana. Secara berdaya guna dan berhasil guna.

4. Mendorong dipatuhinya kebijakan manajemen

\subsubsection{Peran Auditor Internal dalam Proses Pengendalian Internal}

Fungsi audit internal harus mengevaluasi kecukupan dan efektifitas sistem pengendalian intern,yang mencakup governance, kegiatan operasi dan sistem informasi organisasi. Evaluasi sistem pengendalian internal harus mencakup:

1. Efektivitas dan efisiensi kegiatan operasi.

2. Keandalan dan integritas informasi.

3. Kepatuhan terhadap peraturan perundang-undangan yang berlaku.

4. Pengamanan aset organisasi.

Penanggungjawab fungsi audit internal harus mengelola fungsi audit internal secara efektif dan efisien untuk memastikan bahwa kegiatan fungsi tersebut memberikan nilai tambah bagi organisasi sehingga pekerjaan audit memenuhi tujuan dan tanggung jawab umum sebagaimana yang digambarkan dalam charter audit internal yang ditandatangani oleh Pimpinan dan Dewan Pengawas Organisasi dan Manajemen Senior.

Tujuan umum dari proses pengendalian internal adalah untuk mendukung para pihak yang terlibat dalam kegiatan organisasi dalam melakukan pengelolaan risiko dan mencapai tujuan yang telah ditetapkan dan dikomunikasikan oleh organisasi. Auditor internal harus memastikan bahwa manajemen telah menetapkan kriteria yang cukup dan memadai untuk dipakai dalam menentukan apakah tujuan dan sasaran telah tercapai. Pengendalian internal yang baik memberikan jaminan yang kuat bahwa catatan klien dapat diandalkan dan asetnya dilindungi. Pada saat auditor menemukan jenis pengendalian internal yang kuat, jumlah bukti yang dibutuhkan akan lebih sedikit dari pada pengendalian yang lemah. Oleh karena itu, penilaian auditor mengenai pengendalian internal memiliki dampak terhadap proses audit. Beberapa peran yang dapat dibawakan oleh auditor internal adalah

1. Peran sebagai pemecah masalah

Temuan audit pada hakekatnya adalah masalah. Auditor intern harus mampu menggunakan pemecahan masalah (problem solving) yang rasional.

2. Temuan yang ada dari pelaksanaan audit bisa menjurus pada timbulnya konflik bila kurang mampu menyelesaikannya dengan audit.

Selain peran yang dimiliki SPI juga memiliki elemen- elemen yang terdapat dalam Sistem Pengendalian Internal tersebut.

\section{Lingkungan Pengendalian}

Lingkungan Pengendalian dari suatu organisasi menekankan pada berbagai macam faktor yang secara bersamaan mempengaruhi kebijakan dan prosedur pengendalian

\section{Sistem Akuntansi}

Sistem akuntansi tidak hanya digunakan untuk menghasilkan laporan keuangan saja, tetapi juga menghasilkan pengendalian manajemen.

\section{Prosedur Pengendalian}

Prosedur pengendalian merupakan kebijakan dan aturan mengenai kelakuan karyawan yang dibuat untuk menjamin bahwa tujuan pengendali-an manajemen dapat tercapai. Secara umum prosedur pengendalian yang baik terdiri dari:

1. Penggunaan wewenang secara tepat untuk melakukan suatu kegiatan atau transaksi.

Dalam organisasi, setiap transaksi hanya terjadi atas dasar otorisasi dari pejabat yang memiliki wewenang untuk menyetujui terjadinya transaksi tersebut. Oleh karena itu dalam organisasi harus dibuat sistem yang mengatur pembagian wewenang untuk otorisasi atas terlaksananya setiap transaksi. Dengan adanya pembagian wewenang ini akan mempermudah jika akan dilakukan audit trail, karena otorisasi membatasi aktivitas 
transaksi hanya pada orang-orang yang terpilih. Otorisasi mencegah terjadinya penyelewengan transaksi kepada orang lain.

2. Pembagian tugas.

Pembagian tugas memisahkan fungsi operasi dan penyimpanan dari fungsi akuntansi (pencatatan). Dan suatu fungsi tidak boleh melaksanakan semua tahap suatu transaksi. Dengan pemisahakn fungsi operasi dan penyimpanan dari fungsi pencatatan, catatan akuntansi yang disiapkan dapat mencerminkan transaksi yang sesungguhnya terjadi pada fungsi operasi dan fungsi penyimpanan. Jika semua fungsi disatukan, akan membuka kemungkinan terjadinya pencatatan transaksi yang sebenarnya tidak terjadi, sehingga informasi akuntansi yang dihasilkan tidak dapat dipercaya kebenarannya, dan sebagai akibatnya kekayaan organisasi tidak terjamin keamanannya.

3. Pembuatan dan penggunaan dokumen dan catatan yang memadai. Prosedur harus mencakup perancangan dan penggunaan dokumen dan catatan yang memadai untuk membantu meyakinkan adanya pencatatan transaksi dan kejadian secara memadai. Selanjutnya dokumen dan catatan yang memadai akan menghasilkan informasi yang teliti dan dapat dipercaya mengenai kekayaan, utang, pendapatan dan biaya suatu organisasi.(biasanya dilakukan berdampingan dengan penggunaan wewenang secara tepat)

4. Keamanan yang memadai terhadap aset dan catatan.

Keamanan yang memadai meliputi pembatasan akses ke tempat penyimpanan aset dan catatan perusahaan untuk menghindari terjadi-nya pencurian aset dan data/informasi perusahaan.

5. Pengecekan independen terhadap kinerja.

Semua catatan mengenai aktiva yang ada harus dibandingkan (dicek) secara periodik dengan aktiva yang ada secara fisik. Pengecekkan inni harus dilakukan oleh suatu unit organisasi yang independen (selain unit fungsi penyimpanan, unit fungsi operasi dan unit fungsi pencatatan) untuk menjaga objektivitas pemeriksaan.

\section{Penilaian Resiko (Risk Assesment)}

Semua organisasi memiliki risiko, dalam kondisi apapun yang namanya risiko pasti ada dalam suatu aktivitas, baik aktivitas yang berkaitan dengan bisnis (profit dan non profit) maupun non bisnis. Suatu risiko yang telah di identifikasi dapat di analisis dan evaluasi sehingga dapat di perkirakan intensitas dan tindakan yang dapat meminimalkannya.

\section{Informasi dan komunikasi}

Informasi dan komunikasi merupakan elemen-elemen yang penting dari pengendalian intern perusahaan. Informasi tentang lingkungan pengendalian, penilaian risiko, prosedur pengendalian dan monitoring diperlukan oleh manajemen sebagai pedoman operasional dan menjamin ketaatan dengan pelaporan hukum dan peraturan-peraturan yang berlaku pada perusahaan. Informasi juga diperlukan dari pihak luar perusahaan. Manajemen dapat menggunakan informasi jenis ini untuk menilai standar eksternal. Hukum, peristiwa dan kondisi yang berpengaruh pada pengambilan keputusan dan pelaporan eksternal.

\section{METODE PENELITIAN}

\subsection{Jenis Penelitian}

Penelitian ini termasuk penelitian kualitatif dengan analisa deskriptif. Indriyanto \& Supomo (2013:26), menyatakan bahwa penelitian deskriptif merupakan penelitian terhadap masalah-masalah berupa fakta-fakta saat ini dari suatu populasi.

\subsection{Tempat dan Waktu Penelitian}

1. Tempat

Penelitian ini dilakukan pada Perusahaan Daerah Air Minum (PDAM) Airmadidi yang beralamat di Jl. Worang By Pass Airmadidi,Minahasa Utara. 
2. Waktu

Penelitian ini dimulai pada bulan Maret 2017

\subsection{Prosedur Penelitian}

Langkah-langkah dalam pelaksanaan penelitian pada PDAM Airmadidi sebagai berikut.

1. Mengajukan surat permohonan izin penelitian pada pemimpin PDAM Airmadidi.

2. Melakukan pengumpulan data-data pendukung yang akan diperlukan dalam penyusunan, yaitu berupa Struktur Organisasi Perusahaan, Job Description Auditor Internal, Program audit dan Audit yang sudah dilaksanakan di perusahaan.

3. Evaluasi data, setelah semua data yang di dapat telah terkumpul peneliti akan melakukan analisis dengan data-data yang diperoleh dari perusahaan seperti fungsi-fungsi auditor internal yang dilaksanakan pada PDAM Airmadidi dan juga pemeriksaan-pemeriksaan yang dilakukan auditor internal untuk dijadikan bahan dalam menyelesaikan penelitian sehingga mendapatkan kesimpulan.

\subsection{Metode Pengumpulan Data}

\subsubsection{Jenis Data}

\section{Data Kualitatif}

Data kualitatif yaitu data yang disajikan dalam bentuk kata verbal bukan dalam bentuk angka. Yang termasuk data kualitatif dalam penelitian ini yaitu gambaran umum obyek penelitian, meliputi: Sejarah singkat berdirinya, letak geografis obyek, Visi dan Misi, struktur organisasi, Job descriptions auditor internal, program auditor.

\section{Data Kuantitatif}

Data kuantitatif adalah jenis data yang dapat diukur atau dihitung secara langsung, yang berupa informasi atau penjelasan yang dinyatakan dengan bilangan atau berbentuk angka.

\subsubsection{Sumber Data}

Indriyanto \& Supomo (2013:146), menyatakan bahwa sumber data terdiri dari :

1. Data Primer (Primary Data)

Data primer merupakan sumber data penelitian yang diperoleh secara langsung dari sumber asli (tidak melalui media perantara). Data primer secara khusus dikumpulkan oleh peneliti untuk menjawab pertanyaan penelitian. Data primer dapat berupa opini subyek (orang) secara individual atau kelompok, hasil observasi terhadap suatu benda (fisik), kejadian atau kegiatan, dan hasil pengujian. Ada dua metode yang dapat digunakan untuk mengumpulkan data primer, yaitu: (1) wawancara dan (2) observasi. Untuk mendapatkan data primer, penulis melakukan interview dengan pimpinan perusahaan dan bagian-bagian yang terkait dengan penelitian ini untuk mendapatkan data-data yang diperlukan untuk penelitian ini.

\section{Data Sekunder (Secondary Data)}

Data sekunder merupakan data dari penelitian yang diperoleh peneliti secara tidak langsung melalui media perantara (diperoleh dan dicatat pihak lain). Data sekunder umumnya berupa bukti, catatan atau laporan historis yang telah tersusun dalam arsip yang telah dipublikasikan.

\subsubsection{Teknik Pengumpulan Data}

1. Wawancara.

Tanya jawab secara langsung dengan auditor internal serta pihak terkait di PDAM Airmadidi seperti Direktur, supervisor untuk memberikan penjelasan mengenai data yang diperlukan secara face to face yang berhubungan dengan penelitian.

2. Observasi.

Pengamatan secara langsung pada obyek penelitian untuk mengetahui keadaan yang sebenarnya untuk menjawab masalah dari penelitian dengan mengamati apakah auditor internal benar-benar melaksanakan pekerjaannya sesuai dengan informasi yang ia berikan. 


\subsection{Metode Analisis Data}

Adapun Metode Analisis menggunakan Metode Deskriptif, dimana peneliti menguraikan, menjelaskan, serta memaparkan gambaran-gambaran tentang data yang diperoleh peneliti mengenai evaluasi fungsi auditor internal dalam pendeteksian dan pencegahan fraud.

\subsection{Job Description Auditor Internal PDAM Airmadidi}

Ketua Satuan Pemeriksa Intern (SPI) mempunyai tugas:

1. Membantu Direktur dalam melakukan penilaian atas sistem pengendalian, pengelolaan, dan pelaksanaannya serta memberikan saran-saran perbaikan.

2. Secara periodik memberikan penilaian dan pembahasan terhadap seluruh kegiatan perusahaan.

3. Melakukan pemeriksaan terhadap pekerjaan fisik maupun administrasi keuangan.

4. Membantu pelaksanaan pemeriksaan yang dilakukan oleh Dewan Pengawas maupun pemeriksa lainnya.

5. Membuat/menyusun laporan secara periodik setiap bulan.

6. Melakukan tugas-tugas dalam bidangnya yang diberikan oleh Direktur.

7. Dalam menjalankan tugas ketua SPI bertanggung jawab kepada Direktur.

Tabel 4.1

Evaluasi Pemeriksaan Yang Dilakukan Oleh Auditor Internal PDAM Airmadidi

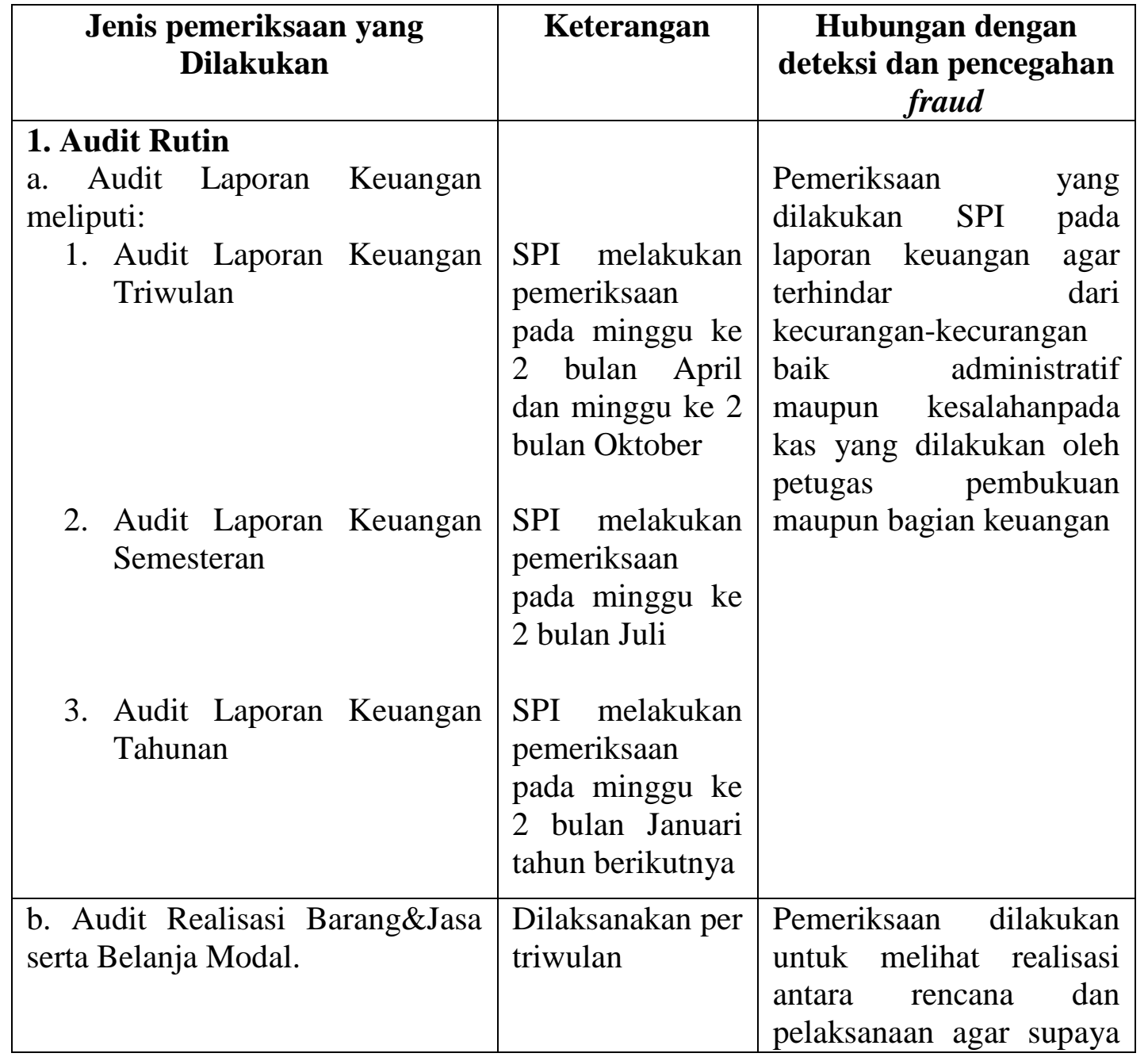




\begin{tabular}{|c|c|c|}
\hline $\begin{array}{c}\text { Jenis pemeriksaan yang } \\
\text { Dilakukan }\end{array}$ & Keterangan & $\begin{array}{c}\text { Hubungan dengan } \\
\text { deteksi dan pencegahan } \\
\text { fraud }\end{array}$ \\
\hline & & $\begin{array}{l}\text { semua kegiatan sesuai } \\
\text { rencana dan pelaksanaan }\end{array}$ \\
\hline c. Audit Piutang Pelanggan & $\begin{array}{l}\text { Dilaksanakan } \\
\text { bersamaan } \\
\text { dengan audit } \\
\text { laporan } \\
\text { keuangan }\end{array}$ & $\begin{array}{l}\text { Pemeriksaan piutang } \\
\text { pelanggan } \\
\text { menghindari terjadinya } \\
\text { piutang tak tertagih dalam } \\
\text { perusahaan }\end{array}$ \\
\hline d. Audit Aset & $\begin{array}{l}\text { Dilaksanakan per } \\
\text { semesteran }\end{array}$ & $\begin{array}{l}\text { Pemeriksaan } \\
\text { perusahaan dilakukan } \\
\text { untuk } \\
\text { terjadinya } \\
\text { penyalahgunaan aset oleh } \\
\text { karyawan maupun pihak } \\
\text { perusahaan yang ingin } \\
\text { melakukan } \\
\text { kecurangan }\end{array}$ \\
\hline e. Audit atas Sambungan Legal & $\begin{array}{l}\text { Dilaksankan } \\
\text { berdasarkan } \\
\text { kebutuhan }\end{array}$ & $\begin{array}{l}\text { SPI dibantu oleh bagian } \\
\text { Teknik melakukan } \\
\text { pemeriksaan } \\
\text { sambungan legal untuk } \\
\text { menghindari terjadinya } \\
\text { pemasangan sambungan } \\
\text { ilegal }\end{array}$ \\
\hline $\begin{array}{l}\text { a. Audit tindak lanjut } \\
\text { LHP ekstern }\end{array}$ & $\begin{array}{l}\text { Dilaksanakan } \\
\text { berdasarkan } \\
\text { permintaan } \\
\text { direksi }\end{array}$ & $\begin{array}{l}\text { Untuk meninjau kembali } \\
\text { temuan-temuan oleh } \\
\text { auditor untuk dapat } \\
\text { memberikan saran } \\
\text { perbaikan setiap kali di } \\
\text { dapati adanya kesalahan } \\
\text { dalam perusahaan agar } \\
\text { tidak terjadi kesalahan } \\
\text { yang berulang kali }\end{array}$ \\
\hline & $\begin{array}{l}\text { Dilaksanakan } \\
\text { berdasarkan } \\
\text { permintaan } \\
\text { direksi }\end{array}$ & $\begin{array}{l}\text { Untuk meninjau setiap } \\
\text { pengembalian } \\
\text { dilakukan oleh PDAM } \\
\text { Airmadidi }\end{array}$ \\
\hline
\end{tabular}




\subsection{Pembahasan}

Tabel 4.3

Evaluasi Fungsi Auditor Internal di PDAM Airmadidi dengan Fungsi Auditor Internal menurut Faiz Zamzani

\begin{tabular}{|c|c|c|}
\hline $\begin{array}{c}\text { Fungsi auditor internal } \\
\text { menurut Faiz Zamzani, dkk } \\
(\mathbf{2 0 1 6 : 3 4 )}\end{array}$ & $\begin{array}{l}\text { Fungsi auditor internal } \\
\text { di PDAM Airmadidi }\end{array}$ & ngan \\
\hline $\begin{array}{l}\text { 1. Mengevaluasi risk exposure } \\
\text { yang berkaitan dengan pencapaian } \\
\text { tujuan organisasi yang strategis. }\end{array}$ & $\begin{array}{l}\text { Auditor internal dalam tugasnya } \\
\text { melakukan pemeriksaan rutin } \\
\text { diantaranya pemeriksaan kas, } \\
\text { piutang pelanggan, audit aset, } \\
\text { audit atas sambungan legal. }\end{array}$ & $\begin{array}{l}\text { Sudah sesuai dan } \\
\text { telah dilaksanakan } \\
\text { oleh auditor internal } \\
\text { dan termasuk dalam } \\
\text { audit rutin }\end{array}$ \\
\hline $\begin{array}{l}\text { 2. Mengevaluasi keandalan dan } \\
\text { intergritas informasi dan cara } \\
\text { yang digunakan } \\
\text { mengidentifikasi, untuk } \\
\text { mengklasifikasi, dan melaporkan } \\
\text { informasi tersebut. }\end{array}$ & $\begin{array}{l}\text { Secara periodik auditor internal } \\
\text { memberikan penilaian dan } \\
\text { pembahasan terhadap seluruh } \\
\text { kegiatan perusahaan, serta } \\
\text { auditor meriviu dan melaporkan } \\
\text { pemeriksaannya baik secara } \\
\text { triwulan maupun semesteran }\end{array}$ & $\begin{array}{l}\text { Sudah sesuai dan } \\
\text { dilaksanakan oleh } \\
\text { auditor internal dalam } \\
\text { audit rutin }\end{array}$ \\
\hline $\begin{array}{l}\text { 3. Mengevaluasi penyediaan } \\
\text { sistem untuk memastikan } \\
\text { kepatuhan dengan kebijakan- } \\
\text { kebijakan, rencana, prosedur, } \\
\text { hukum, dan peraturan yang dapat } \\
\text { memiliki dampak yang signifikan } \\
\text { pada organisasi. }\end{array}$ & $\begin{array}{l}\text { Melakukan pemeriksaan } \\
\text { operasional diantaranya } \\
\text { sistem pengendalian } \\
\text { manajemen, } \\
\text { ketaatan pada peraturan } \\
\text { perundang-undangan yang } \\
\text { berlaku dan ketertiban dalam } \\
\text { pelaksanaannya. }\end{array}$ & $\begin{array}{l}\text { Sudah sesuai dan } \\
\text { dilaksanakan oleh } \\
\text { auditor, termasuk } \\
\text { dalam audit rutin }\end{array}$ \\
\hline 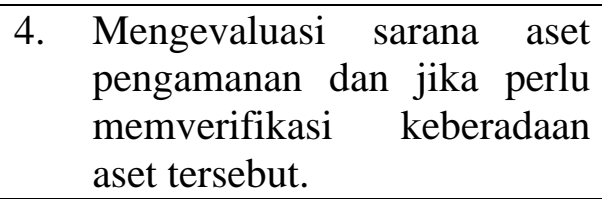 & $\begin{array}{l}\text { Melakukan pemeriksaan } \\
\text { terhadap pekerjaan fisik } \\
\text { maupun administrasi keuangan } \\
\text { diantaranya audit aset. }\end{array}$ & $\begin{array}{l}\text { Sudah sesuai dan } \\
\text { termasuk dalam audit } \\
\text { rutin }\end{array}$ \\
\hline $\begin{array}{l}\text { 5. Mengevaluasi efektivitas dan } \\
\text { efisiensi sumber daya yang } \\
\text { digunakan. }\end{array}$ & $\begin{array}{l}\text { Dalam pemeriksaan rutin } \\
\text { auditor internal melakukan audit } \\
\text { realisasi barang serta belanja } \\
\text { modal serta dalam audit } \\
\text { operasional auditor memeriksa } \\
\text { penggunaan sumber daya, dana } \\
\text { dan sarana. }\end{array}$ & $\begin{array}{l}\text { Sudah sesuai dan } \\
\text { termasuk dalam audit } \\
\text { rutin }\end{array}$ \\
\hline $\begin{array}{l}\text { 6. Mengevaluasi operasi atau } \\
\text { program untuk mamastikan } \\
\text { apakah hasilnya konsisten } \\
\text { dengan tujuan yang dibuat } \\
\text { serta sasaran dan apakah } \\
\text { operasi atau program yang } \\
\text { sedang dilakukan telah sesuai } \\
\text { sebagaimana } \\
\text { direncanakan. }\end{array}$ & 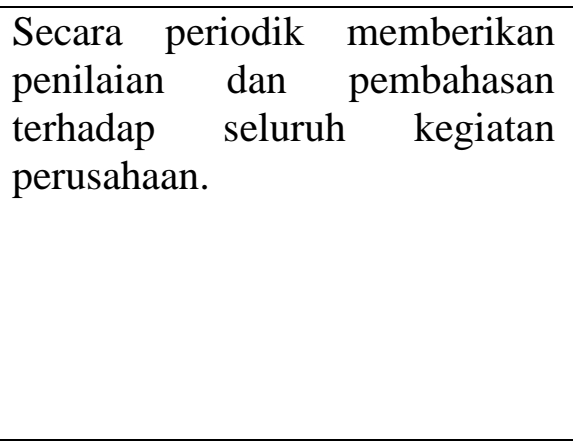 & $\begin{array}{l}\text { Sudah sesuai dan } \\
\text { termasuk dalam audit } \\
\text { rutin }\end{array}$ \\
\hline $\begin{array}{l}\text { 7. Memantau dan mengevaluasi } \\
\text { proses tata kelola. }\end{array}$ & $\begin{array}{l}\text { Auditor melakukan penilaian } \\
\text { atas sistem pengendalian, }\end{array}$ & $\begin{array}{l}\text { Sudah sesuai dan } \\
\text { termasuk dalam audit }\end{array}$ \\
\hline
\end{tabular}




\begin{tabular}{|c|c|c|}
\hline & $\begin{array}{lr}\text { pengelolaan, } & \text { dan } \\
\text { pelaksanaannya } & \text { serta } \\
\text { memberikan } & \text { saran-saran } \\
\text { perbaikan. } & \end{array}$ & rutin \\
\hline $\begin{array}{l}\text { 8. Memantau dan mengevaluasi } \\
\text { efektivitas manajemen risiko } \\
\text { organisasi proses. }\end{array}$ & $\begin{array}{lr}\text { Auditor melakukan penilaian } \\
\text { atas sistem pengendalian, } \\
\text { pengelolaan, } \\
\text { pelaksanaannya } \\
\text { memberikan dan } \\
\text { perbaikan, juga auditor internal } \\
\text { melakukan evaluasi pengelolaan } \\
\begin{array}{l}\text { sumber daya yang ada di } \\
\text { perusahaan }\end{array}\end{array}$ & $\begin{array}{l}\text { Sudah sesuai dan } \\
\text { termasuk dalam audit } \\
\text { rutin }\end{array}$ \\
\hline $\begin{array}{l}\text { 9. Mengevaluasi kualitas kinerja } \\
\text { auditor eksternal dan tingkat } \\
\text { koordinasi dengan audit } \\
\text { internal. }\end{array}$ & $\begin{array}{l}\text { Auditor internal melakukan } \\
\text { pemeriksaan operasional } \\
\text { maupun pemeriksaan keuangan } \\
\text { dan diantaranya terdapat audit } \\
\text { khusus dan audit rutin, dalam } \\
\text { audit khusus auditor internal } \\
\text { melaakukan tindak lanjut LHP } \\
\text { ekstern maupun intern. }\end{array}$ & $\begin{array}{l}\text { Sudah sesuai dan } \\
\text { termasuk dalam audit } \\
\text { khusus }\end{array}$ \\
\hline $\begin{array}{l}\text { 10. Melakukan konsultasi dan } \\
\text { jasa konsultasi terkait dengan } \\
\text { tata kelola, menajemen } \\
\text { risiko, dan control yang } \\
\text { sesuai untuk organisasi. }\end{array}$ & 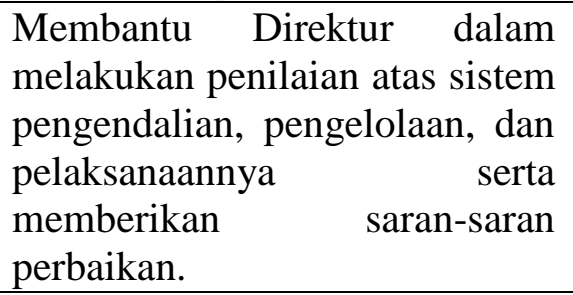 & $\begin{array}{l}\text { Sudah sesuai dan } \\
\text { termasuk dalam audit } \\
\text { khusus }\end{array}$ \\
\hline $\begin{array}{l}\text { 11. Membuat laporan berkala } \\
\text { pada aktivitas audit internal } \\
\text { tentang tujuan, wewenang, } \\
\text { tanggung jawab, dan kinerja } \\
\text { relatif terhadap rencananya. }\end{array}$ & $\begin{array}{l}\text { Membuat/menyusun laporan } \\
\text { secara periodik }\end{array}$ & $\begin{array}{l}\text { Sudah sesuai dan } \\
\text { termasuk dalam audit } \\
\text { rutin }\end{array}$ \\
\hline $\begin{array}{l}\text { 12. Membuat laporan signifikan } \\
\text { risk exposure dan masalah } \\
\text { pengendalian, termasuk risiko } \\
\text { kecurangan, isu-isu } \\
\text { pemerintah, dan hal-hal lain } \\
\text { yang diperlukan atau diminta } \\
\text { oleh dewan. }\end{array}$ & 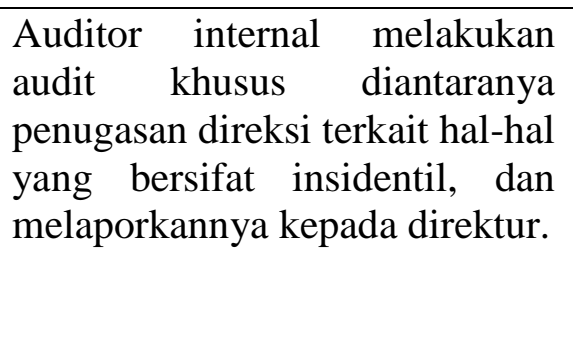 & $\begin{array}{l}\text { Sudah sesuai dan } \\
\text { termasuk dalam audit } \\
\text { khusus }\end{array}$ \\
\hline $\begin{array}{l}\text { 13. Mengevaluasi operasi tertentu } \\
\text { atas permintaan dewan atau } \\
\text { manajemen. }\end{array}$ & $\begin{array}{l}\text { Melakukan tugas-tugas dalam } \\
\text { bidangnya yang diberikan oleh } \\
\text { direktur yang termasuk dalam } \\
\text { audit khusus. }\end{array}$ & $\begin{array}{l}\text { Sudah sesuai dan } \\
\text { termasuk dalam audit } \\
\text { khusus }\end{array}$ \\
\hline
\end{tabular}

\section{Sumber: Hasil olah data}

Tabel 4.3 menjelaskan evaluasi fungsi auditor yang ada di PDAM Airmadidi dapat dilihat auditor internal dalam melaksanakan fungsinya sudah sesuai dengan standar fungsi auditor internal yang diuraikan oleh Faiz,dkk yaitu melakukan evaluasi, memantau, serta 
membuat laporan yang berkaitan dengan hal-hal yang dapat menimbulkan fraud di perusahaan.

Standar audit internal mengakui bahwa pekerjaan auditor internal mungkin meluas melampaui pertimbangan pengendalian internal dalam audit keuangan (reabilitas dan integritas informasi keuangan serta penjagaan aset). Kategori standar praktik mengakui perlunya keahlian, kompetensi, dan kemahiran dalam melaksanakan audit internal. Standar spesifik ditetapkan untuk auditor internal. Standar ini mengakui bahwa auditor harus memiliki pengetahuan, keterampilan, dan disiplin untuk melaksanakan tanggung jawab audit. Standar untuk auditor internal meliputi (1) ketaatan pada standar perilaku, (2) kecakapan dalam hubungan manusia dan komunikasi, (3) Pendidikan profesional yang berkelanjutan. Standar pelaksanaan mengakui setiap bagian yang sangat penting dalam semua audit yaitu perencanaan, pemeriksaan, dan evaluasi bukti, serta pengkomunikasian hasil dan sebelum melaksanakan pekerjaannya auditor terlebih dahulu menyusun tahap-tahap untuk melakukan pemeriksaan di lapangan yang nantinya akan menghasilkan laporan untuk di serahkan kepada Direktur tahapan itu disebut proses audit.

Berdasarkan table 4.1 evaluasi fungsi auditor internal berkaitan dengan pendeteksian dan pencegahan fraud dapat diketahui bahwa auditor internal PDAM Airmadidi sudah melaksankan fungsi auditor internal serta dapat dilihat dari hasil penelitian, pemeriksaan yang dilakukan oleh internal auditor memberikan suatu pendekatan yang sistematis untuk mengevaluasi dan meningkatkan keefektifan manajemen risiko, pengendalian, proses pengaturan dan pengelolaan organisasi serta berdasarkan kegiatan yang sudah dilakukan oleh SPI PDAM Airmadidi dapat dilihat bahwa sudah banyak kegiatan pemeriksaan yang dilakukan untuk dapat mengurangi hal-hal yang tak diinginkan dan dapat dibuktikan bahwa auditor internal pada PDAM Airmadidi sudah dapat mendeteksi dini fraud dalam perusahaan, dengan adanya pemeriksaan rutin yang dilaksanakan oleh SPI maka memberikan tanda awas bagi mereka yang secara sadar atau tidak yang mencoba melakukan hal-hal yang tidak diinginkan contohnya auditor menemukan masih ada kecurangan-kecurangan diantaranya adanya pemasangan saluran air liar yang disebabkan oleh lingkungan pengendalian yang belum di jalankan dengan baik serta perlunya pembinaan terhadap karyawan agar lebih memperhatikan nilai-nilai dalam perusahaan dan lebih bertindak secara efektif dan produktif agar tidak merugikan perusahaan.

Pencegahan fraud bisa dianalogikan dengan penyakit, yaitu lebih baik dicegah dari pada diobati. Jika menunggu terjadinya fraud baru ditangani itu artinya sudah ada kerugian yang terjadi dan telah dinikmati oleh pihak tertentu, bandingkan bila kita berhasil mencegahnya, tentu kerugian belum semuanya beralih ke pelaku fraud tersebut. Bila fraud sudah terjadi maka biaya yang dikeluarkan jauh lebih besar untuk memulihkannya dari pada melakukan pencegahan sejak dini. Untuk melakukan pencegahan, setidaknya ada tiga upaya yang harus dilakukan yaitu:

1. Membangun individu yang didalamnya terdapat trust and openness, mencegah benturan kepentingan, confidential disclosure agreement dan corporate security contract.

2. Membangun sistem pendukung kerja yang meliputi sistem yang terintegrasi, standarisasi kerja, aktifitas control dan sistem rewards and recognition.

3. Membangun sistem monitoring yang didalamnya terkandung control self assessment, internal auditor dan eksternal auditor.

Dalam pencegahan fraud dapat dilihat bahwa SPI melakukan pemeriksaan yang laporannya secara rutin dilaporkan kepada pihak direksi dan juga SPI memberikan saran perbaikan diperusahaan yang nantinya akan ditinjau kembali pelaksanaannya. Berdasarkan uraian yang ada auditor internal dalam perusahaan PDAM Airmadidi menjalankan fungsinya berdasarkan job description yang telah ditentukan oleh perusahaan, program audit oleh auditor internal yang ada di perusahaan serta berdasarkan kriteria yang dimiliki oleh auditor 
internal dalam PDAM Airmadidi baik independensi maupun kompetensi sebagai seorang auditor dan juga dilihat dari tipe penugasan audit diantaranya: (1) Audit Keuangan, (2) Audit Non Keuangan, (3) Audit Tujuan Khusus maka dapat dilihat auditor internal pada PDAM Airmadidi sudah dapat menjalankan pekerjaan sesuai dengan standar fungsi auditor internal atau sudah berdasarkan butir-butir yang terkandung dalam Standar praktik Auditor internal baik dari fungsi audit, standar profesi audit internal, peranan dalam pengendalian internal serta pemeriksaan yang dilakukan oleh auditor baik audit rutin maupun audit khusus yang dilaporkan secara triwulan maupun tahunan kepada Direktur.

\section{KESIMPULAN DAN SARAN}

\subsection{Kesimpulan}

Kesimpulan dari penelitian ini adalah

Auditor internal PDAM Airmadidi sudah menjalankan fungsi sesuai dengan standar fungsi audit dan dapat dilihat auditor internal melakukan berbagai pemeriksaan baik secara rutin maupun khusus dan auditor internal sudah mampu mendeteksi dini fraud di perusahaan berdasarkan program kerja auditor yaitu memeriksa, mengontrol, dan mengevaluasi di tiaptiap bagian dalam perusahaan serta dalam mencegah fraud auditor internal memberikan rekomendasi atas perbaikan, hal ini dapat dilihat dengan laporan-laporan yang disampaikan SPI ke manajemen perusahaan.

\subsection{Saran}

Saran penelitian ini adalah

1. Menciptakan lingkungan pengendalian dan kesadaran manajemen terhadap fungsi SPI.

2. Manajemen harus secara terprogram melaksanakan semua tindak lanjut atas temuan SPI dan manajemen harus benar-benar mamahami fungsi SPI.

\section{DAFTAR PUSTAKA}

Arens, Alvin A.,Randal J. Elder, Mark S. Beasley. 2012. Auditing and Assurance Service : An Integrated Approach. $14^{\text {th }}$ Edition. Pearson Prentice Hall: $\quad$ Sidney. E-Book

Association of Certified Fraud Examiner (ACFE). 2014. Report to the nations on occupational fraud and abuse). USA

COSO, 2013, Internal control-Integrated Framework: Executive Summery, $\quad$ Durham, North Carolina, May 2013.

Ebrahim M. Al-Matari, Abdullah K. Al-Swidi \& Faudziah H. B. Fadzil. 2014. The effect of the internal audit and firm performance: A proposed research framework. International review of management and marketing. Vol.4, No.1. Malaysia.

Indriyanto \& Supomo. 2013. Metodologi Penelitian. Cetakan Keenam. BPFE. Yogyakarta. International Auditing and Assurance Standards Board, Handbook of International Quality Control, Auditing Review, Other assurance and Related Service,Pronouncements, 2013 Edition,volume 1.

Martani. 2012. Akuntansi keuangan menengah berbasis PSAK. Buku 1. Jakarta. Salemba Empat.

Rahadian A.H. 2014. Sistem integritas nasional sebagai kebijakan mencegah dan memberantas korupsi di Indonesia. Volume 1, No.02, Oktober 2014. STIAMI

Sukrisno, Agoes. 2012. Auditing Petunjuk Praktis Pemeriksaan Akuntan oleh Akuntan Publik, Jilid 1, Edisi Keempat, Salemba Empat.

Tanor, Melisa. 2015. Analisis Laporan Graha Internasional Keuangan dalam mengukur kinerja keuangan pada PT. Bank Arta Tbk. Jurnal EMBA. Vol 3 No 3. 
Tuanakotta, M. Theodorus. 2013. Audit berbasis ISA (International Standards on Auditing). Jakarta. Salemba Empat.

Turangan, Feibe Maria, Saerang, David Paul E, Sondakh, Jullie.J. 2016. Pengaruh skeptisisme professional, kompetensi, dan independensi auditor terhadap kualitas pemeriksaan dalam pengawasan keuangan daerah dengan kepatuhan pada kode etik sebagai variable moderating. Goodwill Journal of Accounting and Auditing Research.

Widjaja, Amin. 2016. Pencegahan Dan Pendeteksian Fraud. Penerbit Harvarindo. 2015. Tanya jawab seputar Audit Internal. Harvarindo.

Zamzani Faiz, Ihda Arifin Faiz, Mukhlis. 2016. Audit Internal Konsep dan Praktik (sesuai international standards for the professional practice of internal auditing 2013). Yogyakarta. Gadjah Mada University Press. 